\title{
The Empirics of an Optimal Currency Area in West Africa
}

\author{
Abdoulie Sireh-Jallow ${ }^{1}$ \\ ${ }^{1}$ Country Programs Department, Operations Complex, Islamic Development Bank, Saudi Arabia \\ Correspondence: Abdoulie Sireh-Jallow, Lead Economist, Country Programs Department, Operations Complex, \\ Islamic Development Bank, Saudi Arabia. E-mail: asirehjallow@isdb.org \\ Received: February 4, 2013 \\ Accepted: February 27, 2013 \\ Online Published: March 18, 2013 \\ doi:10.5539/ijef.v5n4p100 \\ URL: http://dx.doi.org/10.5539/ijef.v5n4p100
}

The views expressed in this paper are those of the author and do not reflect those of IDB, its Management, or Executive Directors.

\begin{abstract}
The successes, in the 1990s, of some established currency areas, such as the Euro and the CFA zones, re-awakened interest in their optimality as the inability of individual economies to compete in and maximally benefit from an increasingly globalized world was greatly acknowledged. This fact was not lost on the ECOWAS member countries that agreed to set up a currency union by 2020 . However, the depth of the European sovereign debt crisis and its protracted duration are enough to raise concern in Abuja and other West African capitals as their self-imposed deadline for monetary integration looms. This paper tests the optimality of ECOWAS as a currency area by using two methodologies: a reduced VAR to examine the response of the economies to external price shocks from France, the UK and the US, and a co-integration analysis of the theory of Generalized Purchasing Power Parity (GPPP) to determine the existence of a co-integrating relationship between the exchange rates of four of the currencies that are currently in existence. The results of the study are mixed. The VAR model shows that external shocks from the three foreign countries do not affect all the members similarly. The effects of some of the shocks are statistically insignificant on more than half of the countries. However, the result of the cointegration analysis supports optimality as it identified at least one co-integrating equation and, in some cases, two.
\end{abstract}

Keywords: optimal currency areas, regional integration, co-integration, VAR, ECOWAS

\section{Introduction}

The successes, in the 1990s, of some established currency areas, such as the Euro and the CFA zones, re-awakened interest in currency areas and their optimality as countries recognized that their individual economies are not competitive enough to effectively participate in an increasingly globalizing world. However, the European sovereign debt crisis highlighted the problems and tensions that will inevitably arise within a monetary union when imbalances build up and become unsustainable (Ulrich (2012)). The depth of the crisis and its protracted duration are enough to raise concerns in Abuja and other West African capitals as their self-imposed deadline for monetary integration looms.

The renewed interest of member countries of the Economic Community of West African States (ECOWAS) could be traced back to 1999 when the heads of state agreed to relax the long-held principle that consensus must be reached before a resolution is adopted and implemented, and instead agreed that a group of member countries could proceed to adopt and implement a resolution even if others are not ready. This change, championed by former Presidents Olusegun Obasanjo of Nigeria and Jerry Rawlings of Ghana, set into motion the re-engagement in a monetary integration exercise with renewed vigor to form a monetary union by December 2009. However, by June 2009, it was obvious that this deadline was not feasible because many countries did not reach the convergence criteria and it was decided to extend full integration to 2020 in two stages. Firstly, a West African Monetary Zone (WAMZ) comprising five countries - The Gambia, Ghana, Guinea, Nigeria and Sierra Leone will be formed to launch a single currency called the "Eco" in 2015. Secondly, the Eco will be merged with the CFA franc of the monetary union of eight francophone countries (Note 1) called Union economique monetaire ouest africaine (UEMOA), which is already in existence.

This study is an assessment of the optimality of the ECOWAS sub-region as a currency area using two 
methodologies: (i) a reduced Vector Autoregression (VAR) to examine the response of the economies of the countries that want to form the currency union to external shocks from France, the UK and the USA, and (ii) co-integration analysis of the theory of Generalized Purchasing Power Parity (GPPP) to ascertain the existence of at least one co-integrating relationship between the real exchange rates of four currencies currently in the sub-region (CFA, Dalasi, Naira and Cedi). The study builds on and complements similar studies on West Africa such as Fielding and Shields (1999), Ricci (1997) and Ramirez and Khan (1999).

The paper is divided into seven sections including this introduction. Section two contains a review of the literature on optimal currency areas, section three gives an overview of ECOWAS economies with respect to trade, integration and the convergence criteria, while section four outlines data sources and methodology. Section five contains the theoretical background of the models that anchor the empirical analysis and section six estimates and interpret the models. The paper ends with a summary and conclusions in section seven.

\section{Literature Review}

Renewed interest in "optimal currency areas" (OCA) has spurred continued growth in the literature since the pioneering works of Mundell (1961), McKinnon (1963) and Kenen (1969). Mundell (1961), who can be credited with its birth, identified it by using factor mobility and defined currency areas as "areas within each of which there is factor mobility, but between which there is factor immobility". However, Rose (2006) argues that Mundell's idea of labor mobility is no longer viewed as a viable adjustment mechanism because the nominal rigidities that are responsible for business cycles do not last forever. From a monetary perspective, Scitovsky (1967) and Ingram (1973) used a variant of Mundell's original argument, to argue that financial integration should be a key characteristic of an optimum currency area. From the same perspective, Alesina and Barro (2000) contend that forming a currency union involves trading off the benefits of commitment to price stability against the loss of an independent stabilization policy. Harberler (1970), Fleming (1971), Kindelberler (1973) and others all contributed to the micro foundations of optimal currency areas. Ishiyama (1975) argues in favour of the cost-benefit analysis approach to OCA since the net effect determines which way to go. Corden (1972) argues in favour of limited fiscal integration by contending that monetary integration does not require parallel fiscal integration. On the other hand, Bhatia (1985) argues that a case exists for enforced fiscal integration in a union and maintains that there is a need for a coordinated strategy to diversify and develop the economy. A centralized strategy would be more manageable and efficient than a national one. Using a nested logit regression, Fischer (2011) argues that long-term structural economic variables determine a given country's currency bloc affiliation. Trade integration, he finds, plays a significant role in a country's anchor currency choice, but distance to the location of the central monetary authority is not significant to some. Exploring whether sharing a single currency may set in motion forces bringing countries closer together, De Grauwe and Mongelli (2005) tested the endogeneity of monetary integration and finds different endogeneities at work. However they cautioned for moderate optimism arguing that the strength and pace of endogeneities remains to be seen.

Empirically, various models have been used including VAR models (structural and reduced form), cost benefit analysis (CBA), generalized purchasing power parity and various other indices. Investigating to see if the CFA franc zone of West Africa is an optimal currency area, Fielding and Shields (1999) used a modified method of Blanchard and Quah (1989) to estimate a VAR appropriate for a small open economy, which is the method used in this study. They found that there was a high degree of correlation between inflation shocks on the CFA and those on a representative Anglophone country, Kenya. So, if the policy response to inflation shocks is immediate and inflation is all that matters, the cost of CFA membership to current members is unlikely to be huge. Moreover, the correlation of inflation shocks across the two monetary unions of the CFA is as high as the correlation within them; so there is no particular advantage in having two currencies rather than one although they also found a rather different picture with regard to shocks on output growth. Bergman (1999) also estimated a structural VAR model to examine the symmetry of country-specific structural shocks in Denmark, Norway and Sweden and found that they were not symmetric during the (SCU) union. On the adoption of a regional currency in the Caribbean, Anthony and Hallett (2000) finds that it would not provide any significant gains in the elimination of transaction costs because of the relatively small scale of intra-regional trade. Some countries will benefit more than others, but overall the gains will be insignificant. Similarly, on another part of the world, Tjirongo (1995) used factor mobility, openness of the economy and degree of diversification to assess Namibia's suitability in the Common Monetary Union (CMU) of South Africa, Lesotho, Namibia and Swaziland and concluded that Namibia's nominal exchange rate is not effective as a policy instrument against external shocks from South Africa; however the country could gain positive net benefits from long-term price stability. Looking at a number of supply-side characteristics of Emerging East Asian (EEA) countries, Sanchez (2005) empirically finds that the economies exhibit a high degree of cross-country supply diversity, while there is no compelling 
evidence that shocks are highly correlated across the region.

With respect to the use of the theory of generalized purchasing power parities to explain real exchange rate behaviour in currency areas, Enders and Hurn (1994), Ramirez and Khan (1999), Enders (1995), Mkenda (2001) and Grandes (2003) agree that in the domain of a currency area, the real exchange rate should be stationary. All the same, Rose (2011) argue that it is empirically difficult to compare countries across exchange rates regimes, because it is usually hard to figure out what the regime of a country is in practice, since there are many conflicting regime classifications. The results from several empirical studies on the validity of the purchasing power parity have been mixed. Few studies have found evidence for the theory in the short-run while the results in the long run have been varied. Hakkio (1984) and Dockery \& Georgellis (1994) have found evidence of generalized parity in the short-run. However, Krugman (1978), Dornbush (1980) and Frankel (1981) have found evidence against long-run purchasing power parity.

\section{ECOWAS Economies, Trade and Convergence Criteria}

ECOWAS is composed of 15 countries in West Africa (Note 2). In 2011, it was estimated to have a combined population of 279 million, an average real GDP growth rate of $3.37 \%$, an average per capita GDP of US\$ 715 and an average inflation rate of 7 per cent. These averages mask the huge disparities that exist in the region. The population ranges between 160 million in Nigeria (57\% of the sub-region) and 1.7 million in Guinea Bissau (1\%), while the real GDP growth rate ranged from $7.2 \%$ also in Nigeria to $-4.7 \%$ in Cote D'Ivoire, which is barely recovering from almost a decade of civil strife. The range for per capita GDP is from US\$1,490 in Nigeria to US\$ 370 in Serra Leone while CPI for the period ranged from $21.5 \%$ in Guinea to $2.7 \%$ in Benin. In the same year, ECOWAS merchandise exports amounted to US\$ 154 billion representing more than a $35 \%$ increase over 2010 and is almost double the 10-year average of US\$ 82 billion (WTO 2012). These exports represent about 24 percent of African exports or 0.8 percent of world exports in the year. Meanwhile merchandise imports in the year amounted to US\$ 103 billion, an increase of 16 percent over 2010, and representing 19 percent and 0.6 percent of African and world merchandise imports respectively. The service trade is not quite developed in the ECOWAS region and the total service exports in 2010 amounted to US\$ 8 billion representing almost 11 percent of African service exports but is negligible compared to the world's service exports of US\$ 4.2 trillion in the same year. ECOWAS imports of services in 2010 amounted to US\$ 31 billion, representing 19 percent of African service imports or 0.9 percent of the world's import of services.

Sets of primary and secondary convergence criteria towards which all economies must converge were agreed upon. The former include fiscal deficit of less than 4 percent of GDP, inflation rates in single digits, central bank financing of less than 10 percent of the previous year's tax receipts and gross foreign reserves of at least 3 months of import cover. The latter criteria stipulate that countries must not have any domestic arrears, their tax revenues must be greater than 20 percent of GDP, their wages and salary expenditures must be less than 35 percent of total tax revenue, they must all maintain positive real interest rates and their public investment to tax ratios must be more than $20 \%$ (see Annex Table 1 for details).

\section{Data Sources and Methodology}

Data used in this analysis are primarily from the World Development Indicators database of the World Bank, supplemented with data from the International Financial Statistics (IFS) and from the International Monetary Fund (IMF). As in Fielding and Shield (1999), this paper estimates reduced form vector autoregression (VAR) models for eleven (Note 3 ) of the thirteen ECOWAS countries that want to form a monetary union. The models are used to determine how the output growth and prices of these countries respond to external price shocks from the UK, the US and France. The premise of this methodology is that, for a monetary union to be stable, all the members must be affected in a similar manner, by an external shock. If an external shock positively impacts on some members but negatively on others, then the monetary union will not be stable.

Deriving from Enders' (1995) that the real exchange rates between two countries comprising the domain of an optimal currency area should be co-integrated, the paper also uses co-integration analysis on the theory of Generalized Purchasing Power Parity (GPPP) (Note 4) to determine whether a stable long-run relationship exists between the exchange rates of the four currencies (Note 5) of the countries and the corresponding consumer price indices. Countries qualifying to form a currency union must have their fundamental variables move together on average (see Mkenda (2001) and Ramirez and Khan (1999)). Fielding and Shields (1999) also argue that the cost of monetary union membership will depend on the extent to which price and output shocks are correlated across countries, and the degree of similarity in the long-run effects of the shocks on the macro-economy. 


\section{Theoretical Background}

\subsection{The VAR Model}

As in Fielding and Shields (1999), the dependent variables of the VAR model are the real interest rate growth $(\Delta \mathrm{r})$; nominal money stock growth $(\Delta \mathrm{m})$; and income growth $(\Delta \mathrm{y})$; whilst the independent variable $\left(\Delta \mathrm{p}^{*}\right)$ is the consumer price index (of France, the UK and the US in this paper) multiplied by the rate of nominal exchange rate depreciation. In effect, this study assesses the effects of shocks from three foreign countries. The econometric framework of Fielding and Shields (1999) also apply to this model. The identification of the model is based on the methodological framework initially introduced by Blanchard and Quah (1989) and modified by Fielding and Shield (1999). For each country, a reduced form VAR of Equation (1) is estimated.

$$
X_{t}=A(L) X_{t-1}+e_{t}=(I-A(L))^{-1} e_{t}
$$

Where $A(L)=4 \times 4$ matrix of lag polynomials

$$
X_{t}=4 \mathrm{x} 1 \text { vector of stationary variables }=\left(\Delta p^{*}, \Delta p, \Delta y, \Delta m\right)
$$

$e_{t}=$ Vector of reduced form residuals

The restrictions $A_{12}=A_{13}=A_{14}=0$, i.e., $\Delta p^{*}$ is strictly exogenous, hold. No restrictions are imposed on the reduced form residual co-variance matrix so that the reduced form innovations $e_{t}$ have no obvious economic interpretation.

\subsection{The Generalized Purchasing Power Parity Model}

In its simplest form, the theory of purchasing power parity simply amounts to applying the law of one price. This means that the cost of a basket of goods in The Gambia should be similar to the cost of the same basket of goods in Senegal in the absence of government interventions. As Ramirez and Khan (1999) argue, this is not the case in reality since a number of complications such as differentiated products, tastes and costly information deter this law of one price. The results from several empirical studies on the validity of purchasing power parity have been mixed. Few studies have found evidence for the theory in the short run (Hakkio (1984) and Dockery and Georgellis (1994)), while the results in the long-run have been varied. Krugman (1978), Dornbusch (1980) and Frankel (1981) have found evidence against long-run purchasing power parity. As in Ramirez and Khan (1999), long-run relations are sought between the pairwise exchange rates of the five currencies that are currently circulating in the Community (CFA franc, Gambian Dalasi, Ghanian Cedi and Nigerian Naira) explained by

$$
E_{j t} / E_{i t}=\alpha_{0}+\alpha_{1}\left[\frac{C P I_{j t}}{C P I_{i t}}\right]+\varepsilon_{t}
$$

Where $\quad \mathrm{E}_{\mathrm{j} t} / \mathrm{E}_{\mathrm{it}}=$ Exchange rate of currency of country $i$ with respect to country $j$.

$\mathrm{CPI}_{\mathrm{jt}}=$ Inflation in foreign country.

$\mathrm{CPI}_{\mathrm{it}}=$ Inflation in domestic country.

\section{Empirical Analysis: Estimation and Interpretation of Results}

\subsection{Estimating the VAR Models}

The equations of the VAR model are estimated one at a time using OLS estimation, which, according to Verbeeck (2000), is consistent because the white noise terms are assumed to be independent of the history of the dependent terms. Greene (1993) also contends that because the explanatory variables are the same in each equation, a system estimator, like seemingly unrelated regressions (SUR), provides the same estimates as OLS applied to each equation separately. Having found that the $e_{t}$ are not correlated, each equation of the reduced form VAR is estimated separately using OLS, which yields efficient results since the lags of all the endogenous variables appear in all the equations. Although using Seemingly Unrelated Regression (SUR) estimation would have produced more efficient estimators than OLS, Fielding and Shields (1999) argue that this does not allow for correlation between say $\Delta p$ in one country and $\Delta y$ in another.

The VAR models are estimated for the period 1970 to 2010. Table 1 shows the impact of price shocks from the three foreign countries on the output growth and price changes of the participating ECOWAS member countries. In general, the results of the VAR models find that price changes from these three foreign countries affect almost half of the countries in the Economic Community but the effects are statistically insignificant on an almost equal number of countries. Where the effects are statistically significant, all three price shocks adversely affect output in the countries but directly affect both money demand and consumer prices. 
Table 1. VAR estimation results

\begin{tabular}{|c|c|c|}
\hline $\begin{array}{c}\text { US } \\
\text { price shocks }\end{array}$ & $\begin{array}{c}\text { UK } \\
\text { price shocks }\end{array}$ & $\begin{array}{c}\text { French } \\
\text { price shocks }\end{array}$ \\
\hline \multicolumn{3}{|c|}{ significantly affects GDP growth in } \\
\hline Benin & Benin & Benin \\
\hline Burkina Faso & Burkina Faso & Burkina Faso \\
\hline Cote d'Ivoire & Cote d'Ivoire & Cote d'Ivoire \\
\hline Niger & Gambia & Niger \\
\hline \multirow[t]{2}{*}{ Togo } & Niger & Togo \\
\hline & Togo & \\
\hline \multicolumn{3}{|c|}{ significantly affects real money demand in } \\
\hline Benin & Guinea Bissau & Benin \\
\hline Guinea Bissau & Niger & Cote d'Ivoire \\
\hline Niger & & Guinea Bissau \\
\hline & & Niger \\
\hline \multicolumn{3}{|c|}{ significantly affects counsumer prices in } \\
\hline Benin & Benin & Benin \\
\hline Burkina Faso & Burkina Faso & Burkina Faso \\
\hline Gambia & Nigeria & Nigeria \\
\hline Nigeria & Niger & Niger \\
\hline Niger & Togo & Togo \\
\hline Togo & & \\
\hline
\end{tabular}

Source: Author's computation using WB data.

Specifically, price changes in the US negatively affect output in Benin, Burkina Faso, Cote d'Ivoire, Niger and Togo, while positively impacting on money demand in Benin, Cote d'Ivoire, Guinea Bissau and Niger and prices in Benin, Burkina Faso, The Gambia, Nigeria, Niger and Togo. It is worth noting that the effects are different for The Gambia (there is an inverse relationship). A unit change in US prices affects outputs from these countries within a range of -0.5 to -0.78 , while the range of the changes in money demand is 0.26 to 0.31 , and that for consumer prices is between -0.16 and 0.32 . For the remaining countries the effects of price changes in the US are statistically insignificant (see Annex Table 2 for details).

With respect to UK price shocks, a unit change adversely affects outputs in Benin, Burkina Faso, Cote d'Ivoire, The Gambia, Niger and Togo by between -0.30 and -0.78 ; positively impacts on money demand in Guinea Bissau and Niger by 0.31 and 0.27 respectively; and directly affect prices in Benin, Burkina Faso, Nigeria, Niger and Togo in a range between 0.16 and 0.30 .

With regard to the effects of French price shocks, the study finds that they are more or less similar to those of the US. A unit change inversely affects output in Benin, Burkina Faso, Cote d'Ivoire, Niger and Togo, in the range of -0.55 to -0.60 . As for the effects on money demand, the same countries that are affected by the US price shocks are also affected in addition to Togo and the range in this case is between 0.24 and 0.49 . Alternatively, the effects of French price shocks affect exactly the same countries that are affected by UK price shocks and here the range is between 0.27 and 0.35 .

\subsection{Co-Integration Analysis and the Generalized Purchasing Power Parity (GPPP) Theory}

Countries forming an optimal currency area should exhibit a stable long-run relationship among their exchange rates. In this methodology, Equation (3) is estimated. However, before doing this, the stationarity of the variables is first determined to check if they possess unit roots. The results show that the CFA/Cedi and the Dalasi/Cedi exchange rate series are stationary and do not have unit roots, while the CFA/Dalasi, the CFA/Naira, the Dalasi/Naira and the Cedi/Naira series are all integrated of Order 1. With regard to the inflation rates, those of UEMOA, the product of Senegal and The Gambia rates, and that of The Gambia and Nigeria are integrated of Order 1, those of Ghana/Nigeria and The Gambia are integrated of order 2, whilst the rest are stationary and integrated of Order 0 . The DW statistics also indicate the absence of autocorrelation in the series except for the product of the Senegal/Ghana inflation rates. The non-stationary variables are differenced according to their order of integration and the Johannsen co-integration technique is used to determine if there exists a stable long-run relationship between the real exchange rates of the countries. This is to see if their real exchange rates are co-integrated, a condition for forming an optimal currency area. The results show that there exists at least one co-integrating equation between the real exchange rates of the countries and this supports the optimality of the 
region as a currency area (see Table 2).

Table 2. Number of Cointegrating equations

\begin{tabular}{llcc}
\hline \multicolumn{2}{c}{$\begin{array}{c}\text { Exchange } \\
\text { Rate }\end{array}$} & \multicolumn{1}{c}{ Countries } & \multicolumn{2}{c}{$\begin{array}{c}\text { Number of } \\
\text { Cointegrating }\end{array}$} \\
\cline { 2 - 4 } & & $\begin{array}{c}\text { Trace } \\
\text { test }\end{array}$ & $\begin{array}{c}\text { Max-eigen } \\
\text { value test }\end{array}$ \\
\hline CFA/Dalasi & Senegal-Gambia & 2 & 2 \\
CFA/Cedi & Senegal-Ghana & 2 & 2 \\
Dalasi/Cedi & Senegal-Nigeria & 1 & 1 \\
Dalasi/Naira & Gambia-Ghana & 2 & 2 \\
Cedi/Naira & Ghana-Nigeria & 2 & 2 \\
\hline
\end{tabular}

Source: Author's computation using WB data.

\section{Summary and Conclusions}

The study shows mixed results for the optimality of the ECOWAS region as a currency area. The VAR shows that external shocks from the US, the UK and France significantly affect only half of the eleven members that want to form the currency area. In the remaining cases, the impacts of these shocks are statistically insignificant. This asymmetry would pose a problem for the optimality of the economic community as a currency area. On the other hand, the perspective of generalized purchasing power parity is more conclusive. The co-integration analysis identified the existence of at least one co-integrating equation between the real exchange rates of the countries. As Ender's (1995) argues, the real exchange rates between two countries comprising the domain of an optimal currency area should be co-integrated, therefore this result supports the optimality of ECOWAS as a currency area. Given that half of the results (the GPPP model) support the optimality of ECOWAS as a currency area, while some asymmetrical shocks have been identified by the VAR model, forming an optimal currency area in West Africa, a stable currency union between these countries calls for the prudent development of a comprehensive, compensation mechanism. Learning from the European sovereign debt crisis, it would be equally important to set up a contingency fund that would be adequately funded, especially during boom periods, to support countries in the magnitudes that would be needed if a crisis erupts. In the absence of these two (compensation mechanism and fund), the resulting currency union could be unstable.

\section{Acknowledgements}

This paper benefited immensely from the methodology used in my Ph.D. thesis and as a result, I am very grateful to Jagdish Handa and Franque Grimard for their excellent supervision, Pat Tuck and Elaine Garnham for their encouraging support. Very insightful comments, on various drafts of the paper, were received from Abdullateef Bello, Saidou Sireh Jallow, Yaya Sireh Jallow, Tijan Jallow, Habib Drammeh, Allan Mukungu, Musa Sillah, Abdallah Kiliaki, Binta Janneh and Fatoumatta Jallow for which I am also very grateful. Research assistance from Rodolphe Missinhoun and Dawda Barry and editorial assistance from Momodou Lamin Yaffa are highly appreciated. The errors are all mine.

\section{References}

African Development Bank. (2011). Regional Integration Strategy Paper for West Africa (2011-2015). Tunis: African Development Bank.

Alberto, A., \& Robert, J. B. (2000). Currency Unions. National Bureau Of Economic Research Working Paper 7927. Cambridge: National Bureau Of Economic Research. Retrieved from http://www.nber.org/papers/w7927

Andrew, K. R. (2006). Currency Unions. University of California at Berkeley. Retrieved from http://faculty.haas.berkeley.edu/arose/Palgrave.pdf

Andrew, K. R. (2011). Exchange Rate Regimes in the Modern Era: Fixed, Floating, and Flaky. UC Berkeley, NBER and CEPR, Haas School of Business. Retrieved from http://faculty.haas.berkeley.edu/arose/fff.pdf

Anthony, M. L., \& Hallett, A. H. (2000). Is the Case for Economic and Monetary Union in the Caribbean Realistic? Oxford: Blackwell Publishers Ltd.

Bergman, M. U. (1999). Do Monetary Unions make Economic Sense? Evidence from the Scandinavian Currency Union, 1873-1913. Scandinavian Journal of Economics, 101, 363-377. 
http://dx.doi.org/10.1111/1467-9442.00161

Bhagwati, J. (1997, October 16). Fast Track to Nowhere. The Economist, 21-23.

Bhatia, R. J. (1985). The West African Monetary Union - An Analytical Review. IMF Occasional Papers, 35. Washington DC: International Monetary Fund.

Blanchard, O., \& Quah, D. (1989). The Dynamic Effects of Aggregate Demand and Supply Disturbances. American Economic Review, 79, 655-73.

Christoph, F. (2011). Currency blocs in the 21st century. Deutsche Bundesbank, Discussion Paper, Series 1: Economic Studies. Germany: Deutsche Bundesbank. Retrieved from http://www.bundesbank.de/Redaktion/EN/Downloads/Publications/Discussion_Paper_1/2011/2011_06_03_ dkp_12.pdf?_blob=publicationFile

Corden, M. (1972). Monetary Integration. Essays in International Finance 98. Princeton University. New Jersey, Princeton University.

Enders, W. (1995). Applied Econometric Time Series. New York, NY: John Wiley and Sons.

Enders, W., \& Hurn, S. (1994). Theory and Tests of Generalized Purchasing-Power Parity: Common Trends and Real Exchange Rates in the Pacific Rim. Review of International Economics, 2, 179-190. http://dx.doi.org/10.1111/j.1467-9396.1994.tb00039.x

Estrin, S., Urga, G., \& Lazarova, S. (2001). Testing for Ongoing Convergence in Transition Economies, 1970 to 1988. Journal of Comparative Economics, 29, 677-691. http://dx.doi.org/10.1006/jcec.2001.1736

Fleming, M. J. (1971). On Exchange Rate Unification. The Economic Journal. http://dx.doi.org/10.2307/2229844

Grandes, M. (2003). Macroeconomic convergence in South Africa: The Rand Zone Experience. OECD Development Center Working Paper 231. Paris: Organization for Economic Cooperation and Development. http://dx.doi.org/10.1787/731274772335

Greene, W. H. (1995). Econometric Analysis (2nd ed.). New Jersey, NJ: Prentice Hall.

Hakkio, C. (1984). A Re-examination of the Purchasing Power Parity: A Multi-country and Multi-period Study. Journal on International Economics, 17, 265-278. http://dx.doi.org/10.1016/0022-1996(84)90023-0

Harberler, G. (1970). The International Monetary System: Some Recent Developments and Discussions. In G. M. Halm (Ed.), Approaches to greater flexibilities in exchange rates: The Burgenstock papers. Princeton, New Jersey: Princeton University Press.

Ingram, J. (1973). The Case of European Monetary Integration. Princeton University Essays in International Finance. Princeton: New Jersey Press.

International Monetary Fund. (2012). International Financial Statistics. Retrieved September 2012 from http://elibrary-data.imf.org/

Ishiyama, Y. (1975). The Theory of Optimum Currency Areas. IMF Staff Papers, 344-383. Washington DC: International Monetary Fund.

Jonung, L., \& Sjöholm, F. (1993). Should Finland and Sweden form a Monetary Union? Stockholm School of Economics Working Papers Series in Economics and Finance, 224. Retrieved from http://ideas.repec.org/p/hhs/hastef/0224.html

Kenen, P. (2000). Currency Areas Policy Domains and the Institutionalization of Fixed Exchange Rates. Centre for Economic Performance, London School of Economic and Political Science. London: London School of Economic and Political Science.

Kenen, P. B. (1969). The Theory of Optimum Currency Areas: An Eclectic View. In Mundell, R. A., \& Swoboda, A. K. (Eds.), Monetary Problems of the International Economy. The University of Chicago Press.

Marcelo, S. (2005). Is time ripe for a currency union in Emerging East Asia. European Central Bank Working Paper Series, No. 567. Frankfurt: European Central Bank. Retrieved from http://www.ecb.int/pub/pdf/scpwps/ecbwp567.pdf

McKinnon, R. I. (1963). Optimum Currency Areas. The American Economic Review, 53, 717-725.

Mkenda, B. K. (2001). Is East Africa and Optimum Currency Area? Department of Economics. Goteborg University Working Papers in Economics, 4. Goteborg: Goteborg University. 
Mundel, R. A. (1961). A theory of Optimum Currency Areas. The America Economic Review, 60, 657-665.

Paul, D. G., \& Francesco, P. M. (2005). Endogeneities of Optimum Currency Areas - What brings countries sharing a single currency closer together? European Central Bank Working Paper Series, No. 468. Frankfurt: $\quad$ European Central Bank. from http://www.ecb.europa.eu/pub/pdf/scpwps/ecbwp468.pdf

Ramirez, M. D., \& Khan, S. (1999). A Co-integration Analysis of Purchasing Power Parity: 1973-96. International Advances in Economic Research, 369-385. http://dx.doi.org/10.1007/BF02296418

Ricci, L. A. (1997). A Model of an Optimal Currency Area. IMF Working Paper 76. Washington DC: International Monetary Fund.

Scitovsky, T. (1967). The Theory of Balance of Payment Adjustment. Journal of Political Economy, 75, 523-531. http://dx.doi.org/10.1086/259326

Tjirongo, M. T. (1995). Short Term Stabilisation Versus Long Term Price Stability: Evaluating Namibia's Membership of the Common Monetary Area. Centre of the Study of African Economics Working Paper Series, 95-18. Oxford.

Ulrich, V. (2012). Lessons of the European Crisis for Regional Monetary and Financial Integration in East Asia. Asian Development Bank Institute Working Paper Series, No. 347. Manila: Asian Development Bank Institute. Retrieved from http://www.adbi.org/files/2012.02.21.wp347.lessons.european.crisis.east.asia.pdf

Verbeek, M. (2000). A Guide to Modern Econometrics. New York, NY: John Wiley and Sons.

World Bank. (2012). World Development Indicators. Retrieved September 2012 from http://databank.worldbank.org/ddp/home/do

World Trade Organization. (2012). International Trade Statistics. Retrieved September 2012 from http://www.wto.org/english/res_e/statis_e/its_e.htm

\section{Notes}

Note 1. These are Benin, Burkina Faso, Cote D'Ivoire, Mali, Niger, Senegal, Togo and Guinea- Bissau.

Note 2. Benin, Burkina Faso, Cape Verde, Cote D’Ivoire, The Gambia, Ghana, Guinea, Guinea Bissau, Liberia, Mali, Niger, Nigeria, Senegal, Sierra Leone and Togo.

Note 3. Guinea Conakry and Sierra Leone were dropped from this analysis due to the lack of data. Missing data are estimated using the annual growth rate of the actual data.

Note 4. GPPP theory contends that in the absence of government interventions, the price of a basket of goods would cost the same in The Gambia as in Senegal.

Note 5. These are the CFA, the Dalasi, the Cedi and the Naira. Again the currencies of Guinea and Sierra Leone have been dropped because of lack of data.

\section{Appendix}

Appendix 1. ECOWAS convergence criteria

\begin{tabular}{ll}
\hline \multicolumn{1}{c}{ Crite ria } & Target \\
\hline Primary & $\geq-4 \%$ \\
Fiscal Balance / GDP & $\leq 5 \%$ \\
Inflation Rate (End-period) & $\geq 6$ months \\
Gross Foreign Reserves (in months of imports) & $\leq 10 \%$ \\
Central Bank Financing of Budget Deficit in relation to & \\
previous years Tax Revenue & \\
& \\
Secondary & $\leq$ by 2003 \\
Change in Domestic Arrears & $\geq 20 \%$ \\
Tax Revenue (\% of GDP) & $\leq 35 \%$ \\
Wage Bill/Tax Revenue & $>20 \%$ \\
Domestically Financed Investment/Domestic Revenue & Stable rates \\
Nominal Exchange Rate & $>10 \%$ \\
Real Interest Rate &
\end{tabular}

Source: African Development Bank. 
Appendix 2. Vector autoregression estimates

\begin{tabular}{|c|c|c|c|c|c|c|c|c|c|}
\hline & \multicolumn{3}{|c|}{ Effects of US price shocks } & \multicolumn{3}{|c|}{ Effects of UK price shocks } & \multicolumn{3}{|c|}{ Effects of French price shocks } \\
\hline & Coefficient & t-statistic & Adj. $R^{2}$ & Coefficient & t-statistic & Adj. $R^{2}$ & Coefficient & t-statistic & Adj. $R^{2}$ \\
\hline \multicolumn{10}{|c|}{ GDP } \\
\hline Benin & -0.653 & {$[-6.793]$} & 0.571 & -0.670 & {$[-5.221]$} & 0.439 & -0.601 & {$[-4.027]$} & 0.315 \\
\hline Burkina Faso & -0.640 & {$[-4.396]$} & 0.365 & -0.617 & {$[-6.164]$} & 0.510 & -0.554 & {$[-5.609]$} & 0.461 \\
\hline Cote d'Ivoire & -0.690 & {$[-4.522]$} & 0.521 & -0.779 & {$[-4.914]$} & 0.552 & -0.584 & {$[-4.055]$} & 0.483 \\
\hline Gambia & -0.169 & {$[-1.049]$} & 0.002 & -0.306 & {$[-2.324]$} & 0.139 & -0.177 & {$[-1.120]$} & 0.009 \\
\hline Guinea Bissau & -0.054 & {$[-0.510$} & 0.122 & -0.058 & {$[-0.553]$} & 0.124 & -0.050 & {$[-0.473]$} & 0.121 \\
\hline Ghana & -0.076 & {$[-0.218$} & -0.185 & -0.041 & {$[-0.119]$} & -0.187 & -0.031 & {$[-0.159]$} & -0.085 \\
\hline Mali & -0.163 & {$[-1.453]$} & 0.014 & -0.170 & {$[-1.501]$} & 0.020 & -0.160 & {$[-1.461]$} & 0.015 \\
\hline Nigeria & -0.098 & {$[-0.302]$} & -0.172 & -0.253 & {$[-0.767]$} & -0.146 & -0.177 & {$[-0.568]$} & -0.160 \\
\hline Niger & -0.566 & {$[-3.134]$} & 0.252 & -0.582 & {$[-3.200]$} & 0.262 & -0.586 & {$[-3.380]$} & 0.288 \\
\hline Senegal & 0.023 & [0.262] & -0.018 & 0.028 & [0.318] & -0.017 & 0.0155 & [0.172] & -0.020 \\
\hline Togo & -0.781 & {$[-5.321]$} & 0.458 & -0.779 & {$[-5.179]$} & 0.441 & -0.600 & {$[-4.390]$} & 0.376 \\
\hline \multicolumn{10}{|c|}{ Money demand } \\
\hline Benin & 0.321 & [2.119] & 0.051 & 0.256 & [1.383] & -0.017 & 0.485 & {$[2.697]$} & 0.115 \\
\hline Burkina Faso & 0.072 & {$[0.447]$} & -0.209 & 0.0246 & {$[0.204]$} & -0.031 & 0.0571 & {$[0.505]$} & -0.025 \\
\hline Cote d'Ivoire & 0.258 & {$[1.974]$} & 0.322 & 0.240 & [1.689] & 0.303 & 0.244 & [2.065] & 0.329 \\
\hline Gambia & -0.179 & {$[-1.805]$} & 0.187 & -0.111 & {$[-1.348]$} & 0.267 & -0.159 & {$[-1.605]$} & 0.165 \\
\hline Guinea Bissau & 0.310 & [2.409] & 0.386 & 0.305 & [2.413] & 0.387 & 0.316 & [2.514] & 0.398 \\
\hline Ghana & -0.305 & {$[-1.016]$} & -0.025 & -0.270 & {$[-0.911]$} & -0.034 & 0.069 & [0.393] & -0.002 \\
\hline Mali & -0.039 & {$[-0.696]$} & 0.024 & -0.047 & {$[-0.833]$} & 0.033 & -0.035 & {$[-0.640]$} & 0.021 \\
\hline Nigeria & 0.008 & {$[0.040]$} & 0.305 & -0.026 & {$[-0.128]$} & 0.305 & 0.007 & {$[0.040]$} & 0.305 \\
\hline Niger & 0.276 & [2.407] & 0.148 & 0.267 & [2.267] & 0.128 & 0.241 & [2.078] & 0.100 \\
\hline Senegal & -0.050 & {$[-1.208]$} & -0.019 & -0.053 & {$[-1.343]$} & -0.005 & -0.047 & {$[-1.155]$} & -0.025 \\
\hline Togo & 0.186 & [1.263] & 0.022 & 0.216 & [ 1.475$]$ & 0.046 & 0.297 & [2.358] & 0.136 \\
\hline \multicolumn{10}{|c|}{ Consumer price } \\
\hline Benin & 0.219 & 5.244 & 0.408 & 0.294 & [ 7.036] & 0.564 & 0.350 & 10.330 & 0.741 \\
\hline Burkina Faso & 0.182 & [1.961] & 0.060 & 0.160 & [2.178] & 0.055 & 0.189 & [2.853] & 0.131 \\
\hline Cote d'Ivoire & 0.061 & {$[0.733]$} & 0.259 & 0.014 & {$[0.156]$} & 0.247 & 0.062 & [0.818] & 0.261 \\
\hline Gambia & -0.161 & {$[-2.059]$} & 0.526 & -0.102 & {$[-1.442]$} & 0.4360 & -0.139 & {$[-1.760]$} & 0.504 \\
\hline Guinea Bissau & 0.027 & {$[0.368]$} & 0.519 & 0.018 & [0.248] & 0.518 & 0.033 & {$[0.460]$} & 0.521 \\
\hline Ghana & -0.225 & {$[-0.690]$} & 0.287 & -0.283 & {$[-0.893]$} & 0.297 & 0.147 & {$[0.706]$} & 0.146 \\
\hline Mali & -0.001 & {$[-0.046]$} & 0.040 & -0.003 & {$[-0.082]$} & 0.041 & -0.004 & {$[-0.114]$} & 0.041 \\
\hline Nigeria & 0.323 & [2.729] & 0.669 & 0.301 & [2.409] & 0.650 & 0.334 & [2.993] & 0.685 \\
\hline Niger & 0.273 & [2.903] & 0.419 & 0.253 & [2.570] & 0.382 & 0.265 & [2.845] & 0.413 \\
\hline Senegal & -0.068 & {$[-1.606]$} & 0.211 & -0.070 & {$[-1.727]$} & 0.224 & -0.063 & [-1.485] & 0.199 \\
\hline Togo & 0.260 & [3.096] & 0.384 & 0.239 & [2.736] & 0.341 & 0.278 & [ 4.048] & 0.386 \\
\hline
\end{tabular}

Source: Author's computation using WB data. 